\title{
Psychoanalysis of the Characters in ScHneider's The Beginning of Everything
}

\author{
I Gusti Ayu Agung Diah Sri Utami \\ English Department - Faculty of Arts - Udayana University \\ [agungdiah82@yahoo.com] \\ *Corresponding Author
}

\begin{abstract}
The title of this study is Psychoanalysis of the Characters in Schneider's The Beginning of Everything where its aim was to find out the characterization of the characters, as well as the three major personalities concerning the Id, Ego, and Superego of the characters that are presented in the novel. The data in this study were taken from a novel entitled The Beginning of Everything written by Robyn ScHneider in 2013. The data were collected by using the documentation method supported by the note taking technique. In analyzing the data, the study applied the qualitative method and supported by the narrative descriptive technique.The theories used were two different kinds, the first one is from How to Analyze Fiction proposed by Kenney (1966), the second one is Theory of Psychoanalysis proposed by Freud (1896). The result of the study shows that the characterization of the characters could change according to the situations they are facing. The relationship between the Id, Ego, and Superego that was mentioned by Freud are applied in the novel where it has influenced every decision taken by the characters.
\end{abstract}

Keywords: Characters, characterization, psychoanalysis

\begin{abstract}
Abstrak
Judul penelitian ini adalah Psychoanalysis of the Characters in Schneider's The Beginning of Everything dimana tujuannya adalah untuk mengidentifikasi karakterisasi dari suatu karakter, selain tiga kepribadian utama mengenai Id, Ego, dan Superego dari suatu karakter yang digambarkan di dalam novel. Data yang disajikan dalam penelitian ini diambil dari sebuah novel berjudul The Beginning of Everything yang ditulis oleh Robyn ScHneider pada tahun 2013.Dalam pengumpulan data, penelitian ini menggunakan metode dokumentasi dan didukung dengan teknik pencatatan. Dalam menganalisa data, penelitian ini menggunakan metode kualitatif dan didukung dengan teknik naratif-deskriptif. Terdapat dua teori yang berbeda yang digunakan dalam penelitian ini, teori pertama berjudul How to Analyze Fiction yang dikemukakan oleh Kenney (1966), dan teori yang kedua berjudul Theory of Psychoanalysis yang dikemukakan oleh Freud (1896). Hasil dari penelitian ini menunjukkan bahwa karakterisasi dari suatu karakter dapat berubah berdasarkan pada situasi yang dialami oleh suatu karakter. Hubungan diantara Id, Ego, dan Superego yang telah disinggung oleh Freud telah diterapkan di dalam novel dimana itu telah mempengaruhi setiap keputusan yang diambil oleh karakter-karakter tersebut.
\end{abstract}

Kata kunci: Karakter, karakterisasi, psikoanalisis 


\section{Background of the Study}

Novel is one of an author's works which describes how a character is presented. It also describes events that are happening in the novel. Novels are considered to be fictional. When analyzing novel as a part of a study, it shows whether the storyline or the thoughts of the characters are based on the author's psychology or not.

Before analyzing the characters' psychological condition, the characterizations of the characters are going to be discussed. Literature and psychology are related to each other. Literature reflects human life such as feelings, thoughts, imaginations and perception that could be viewed by the personal judgment. Psychology of literature is the psychological study of the authors as a creative process. It is also a study of psychology where the laws are presented within the works of literature that affects the readers upon its stories. (Welleck and Warren. 1970:81).

According to Freud (1896), psychoanalysis works within the concept of unconsciousness. The unconsciousness is described as a painful experience, emotion, wound, fear, guilty desire and unresolved conflict that the characters do not want to know. The relationship between literature and psychoanalysis is that psychoanalysis introduces concept of unconsciousness within the language. All the works are produced from the author's mind, whether it is consciously or unconsciously.

In this study, a novel entitled The Beginning of Everything (2013) by Robyn ScHneider is chosen to be analyzed since the characters in the novel have undergone many new and challenging experiences in their life that they have never felt. These experiences made them go through a lot. It is an interesting novel since it can build an atmosphere that affects the emotion and feelings of the readers.

\section{Problems of the Study}

a. What method of characterization is used in The Beginning of Everything?

b. How are the psychological conditions of the characters presented in The Beginning of Everything?

\section{Aims of the Study}

a. To find out the methods of characterization used in The Beginning of Everything.

b. To find out the psychological condition of the characters in The Beginning of Everything.

\section{Research Method}

The research method used in this study is divided into four points, they are the data source, the method and technique of collecting data, the method and technique of analyzing data, and the method and technique of presenting analysis. Each point will be elaborated as follows:

\subsection{Data Source}

The data in this study were taken from a novel entitled The Beginning of Everything written by Robyn ScHneider in 2013. This novel was chosen to be used in analysis of psychoanalysis because this novel is considered to be an example of finding and learning the psychological conditions of the characters in the story written by Robyn ScHneider in 2013. The novel has unpredictable twists where it could build an atmosphere that affects the emotion and feelings of the readers. The readers could relate the characters with these feelings in this story. This book received critics because of its storyline, but a lot of readers enjoyed reading this book. Some readers could relate to Ezra and felt his 
pain, but some just thought that the storyline was boring. A comment made by Cait (2013) saying that the novel was tedious and slow that left the reader unsatisfied and angry. Half of the comment is right saying that the story is slow but as it goes to the next chapter, it shows interesting events that happen to the characters. This novel is not excellent but is considered to be a good novel because it teaches people that it is not as easy as it looks like to achieve what they want but they need to work hard in order to achieve it.

\subsection{Method and Technique of Collecting Data}

Method and technique of collecting data are the procedures required in order to do the analysis of the study. This study applied the documentation method and is supported by the note taking technique. Documentation method is a social research method and is an important research tool in its own right, and is an invaluable part of most schemes of triangulation, the combination of methodologies in the study of the same phenomenon (Bowen, 2009).

There are a few steps in collecting the data. The first one is the understanding of the methods in the characterization of characters. The second one is comprehending the concepts of psychological analysis. The third one is giving signs or symbols or even taking notes at the statements from the plot established by the characters. The last one is determining the characters' attitudes and how their psychological state is through their statements.

\subsection{Method and Technique of Analyzing Data \\ Method and technique of analyzing data are the processes by which the collected data are analyzed. This study}

applied qualitative method along with descriptive technique. Qualitative research is an empirical research where the data are not in the form of numbers (Punch, 1998). Descriptive technique is applied in this story because psychology or the psychological state of the characters can only be described from the conversations and from the way they treat others. The collected data are analyzed by using the theory of Characters in the Methods of Character Portrayal proposed by Kenney (1966:34) and "Theory of Psychoanalysis" proposed by Sigmund Freud (1896). These two theories are used in the study because they are considered to be suitable theories compared to other theories that have been read. These theories are more precise in describing characters.

\subsection{Method and Technique of Presenting Data Analysis}

Method and technique of presenting analysis is how we present the analysis in the thesis. The qualitative method is also applied in presenting the data analysis and supported by narrative descriptive technique. Therefore, the analysis will not be in a table of content but it will be presented in descriptive writing.

\section{Analysis}

The characters are the most important element from the novel because each character shows how their personalities are through their words and actions in the novel.

\subsection{Relationship of the Characters in the novel The Beginning of Everything by Robyn ScHneider}

The relationships of the characters are necessary to be shown because it will be easier to determine the behavior of one character to the other, as well as to 
know the extent or closeness of the characters.

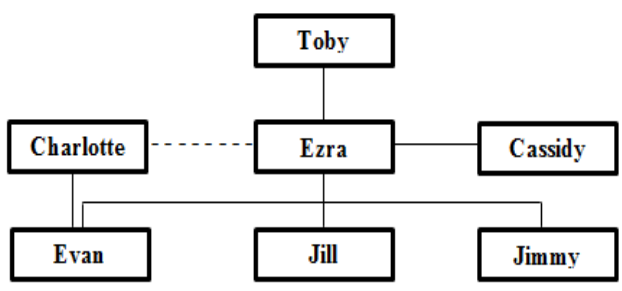

- - - - - - indicates a bad relationship indicates a good relationship

Ezra is the main character in the story where he has a best friend named Toby. They always spend their time together since they were kids. In High School, Ezra met Charlotte, Evan, Jill, Jimmy, and Cassidy. He and Charlotte were once in a relationship until Charlotte cheated on Ezra where it made her and Ezra's relationship pretty bad. They do not even talk to each other in case it turns into an awkward situation. Ezra, Evan, Jill and Jimmy are friends where they often hang-out together in school.

During the freshman year, Ezra met a girl named Cassidy. She is a new student who knew Toby from her previous school. When she went to Eastwood High and met Toby again, she learned about Ezra and Toby not being close where she tried to help them become best friends once again by hanging out with them every day at school.

\subsection{Analysis of the Characterization}

The characterization of the characters are classified into five points according to Kenney, and those are discursive method, character on character method, dramatic method, contextual method, and mixing method.

\subsubsection{The Analysis of the Discursive Method}

Discursive method is a direct method used by authors if they want to describe their character in a simple and easy way. This method is counted to be an easy way to describe a character because by using this method, the readers know exactly how a character is since a character's character is explained right to the point about who is being characterized. It has a disadvantage where it does not really make the readers curious about a character because it is already described clearly by the author. (Kenney. 1966: 34) Data 1

I had just turned seventeen, was embarrassingly popular, earned good grades, and was threatening to become eternally extraordinary. (ScHneider. 2013: 05)

Referring to the above data, Ezra was described physiologically and sociologically. Ezra was a High School student who was a smart seventeen years old boy. He was part of the basketball team and he dated the most beautiful girl at school. Lots of students were really envious of him thinking how perfect his life was. In middle school, he went to an amusement park with his best friend, Toby, and when they were riding a roller coaster, they went through an embarrassing incident that they could not forget. He had lots of friends at school but since they knew the incident that happened to Ezra when he was in middle school, they started to tease him till it got to a point where he became unexpectedly popular but in an embarrassing way. Surprisingly, not only his close friends knew it, the students who are not even in his class also knew and they looked at him weirdly.

\subsubsection{The Analysis of the Character on Character Method}

Character on character method is an indirect way to describe a character used by authors. It does not describe a character in a direct way but instead it 
describes it through another character's speech or talks. Authors use this type of method in order to make their readers more curious about how a character in the story is and also to make the story more interesting. Below are some quotations about how a character is described through other characters' conversations.

Data 2

I thought about it sometimes, as we drifted apart over the years, as Toby faded into obscurity and I became an inexplicable social success. (ScHneider. 2013: 04)

According to the above data, Ezra and Toby was described psychologically. It is an example for the character on character method where Ezra described how he and Toby were after the incident that happened in middle school. According to Ezra, Toby started to shut himself from the outside world where people around him began to forget his existence. As for Ezra, he was already famous at school but then he suddenly became more famous that he used to be and was known by lots of people. He could not understand the reason why he became famous very suddenly and was wondering whether it was because of the incident that happened with him and Toby or because of something else.

\subsubsection{The Analysis of the Dramatic Method}

A character is shown through their actions and words. It invites the readers' interest to read the story to know how a character is like. The advantage of this method is that it should be obvious; however, the disadvantage of this method is that it takes longer to describe how a character is. Also, it increases the possibility of misjudging the character.

Data 3
Cassidy had turned up at a debate tournament dressed as a boy, complete with an enormous fake mustache, and still won. That Cassidy had organized a flash mob where more than one hundred strangers showed up at a graveyard in San Francisco dressed as zombies and had an enormous pillow fight. That she'd spent a summer modeling for teen book covers. (ScHneider. 2013: 60)

The above data shows an example of a dramatic method. The above data shows how Cassidy is psychologically through the actions or things that she had done. Cassidy is considered to be a smart, hardworking lucky person. Before going to Eastwood High, Cassidy went to the same school as Toby but she suddenly stopped coming to school and she somehow vanished into thin air. At the previous school, she once won a debate tournament even though she violated the dress code by dressing as a boy with a fake moustache. She was considered to be a weird person as well. She once organized a flash mob in a graveyard joined by one hundred strangers dressed as zombies, and she also sold T-shirts with her face on it. She was also a person who spent her summer working as a model for teen book covers.

\subsubsection{The Analysis of the Contextual Method}

Contextual method is used when describing a character through the verbal context that surround a character. So, a character is defined through their surroundings. For instance, if a character is consistently described as a beast of prey, then the reader may well conclude that the author is trying to tell them something.

Data 4 
"How about you take her instead?" I suggested, and then I turned and walked back down the hallway. (ScHneider. 2013: 10)

The above data depicts how Ezra's reaction was after seeing Charlotte cheated with a senior. After waiting so long for Charlotte to reply to his message, Ezra decided to go to a party hoping to meet Charlotte there, but to his surprise, he found Charlotte cheated on him with a senior; he tried to be cool with what happened there. He tried to be calm without looking sad or devastated by what Charlotte did to him. He made it seems like he was fine with everything that had happened to him and he broke up with her instantly and left the place.

\subsubsection{The Analysis of the Mixing Method}

Mixing method is used by authors who want to describe a character using various kinds of method. In fictional stories, using one method is very rare when it comes to describing a character. Two or more are used by authors to prevent the readers from being less interested in their story.

Data 5

She'd cooked salmon with quinoa and kale, and not to sound ungrateful or anything, but my father and I would have preferred pizza. But we didn't say anything. You never can, to my mom. (ScHneider. 2013: 41)

This is a mix method because it uses two methods in one paragraph. It contains the character on character method and the dramatic method. It described Ezra's mother's character but with Ezra describing how she was. His mother was a person who really loves her family a lot. According to Ezra, she did not want her family to eat junk foods so she tried her best to keep them healthy by serving them healthy foods. She was also a kind-hearted person but she did not want to listen to any critics that were given to any foods that were cooked by her. Ezra and his dad were always quiet and ate whatever being served by his mother.

\subsection{Analysis of the Psychology}

The psychoanalysis according to Freud is classified into three major personalities, those are the Id, Ego, and Superego.

\subsubsection{The Analysis of The Id}

Id is the basic psychological level where the wants or needs are the control. These wants and needs are present since a person was born. It is a part of unconscious mind that needs to be fulfilled immediately. Id does not stay in touch with the external world and it does not change with time or experience. So, Id is not affected by reality, logic, or even the everyday world, since it operates within the unconscious part of the mind.

Data 6

I let my cane clatter to the ground and limped toward the back line of the court. I had to know how bad it was, to see for myself if it was true what the doctors had said - that sports were finished. (ScHneider. 2013: 15)

On the day Ezra caught Charlotte cheating on him, he got into an accident where he hurt his hand and knee. The doctor said that his hand would be healed but not with his knee. The accident had a major impact to his future since Ezra was a person who loved sports more than anything else; but now he was told that his knee cannot be healed which means that he needs to leave sports and do something else that does not have any relationship with using his knee. Ezra could not believe what he heard and 
wanted to prove to himself that the doctor was wrong. He had the curiosity in him where he wanted to proof it as soon as possible. This is called the Id. A curiosity rose inside him and later he would try to prove it by doing some actions called Ego.

\subsubsection{The Analysis of The Ego}

Different from Id, Ego is a part of Id that is affected by the external world. Ego operates based on the reality found in realistic ways and it is often compromising or postponing satisfaction to avoid negative consequences of society. Ego works with reason, whereas Id is chaotic and unreasonable. Ego seeks pleasure but avoids pain and has no concept of right or wrong as long as the id's fulfilled.

Data 7

Barely daring to breathe, I tossed the ball high and felt it connect with the racquet in a way that, while not entirely pleasant, was at least tolerable. It landed neatly in the center of the square without any heat. I'd been aiming for the back right corner, but I'd take it. (ScHneider. 2013: 15)

From the want or Id that Ezra had earlier, he wanted to satisfy his curiosity by proofing to himself that the doctor's word was wrong. He tried to proof to himself about what the doctor said by trying to play tennis so that his curiosity or his Id could be fulfilled. What he did was that he worked on a realistic way to satisfy his Id demand. He played tennis even though he was not fully cured where he threw the ball and it landed in the center. He was not aiming for center but he accepted it since his hand and knee were not fully healed.

\subsubsection{The Analysis of The Superego}

The superego is based on judgments and morals about what is right and what is wrong. It is influenced by the values and morals of society which are learned from parents, families, or others. Superego's function is to control the Id's impulses, especially those that are forbidden in society. It also has the function of persuading the Ego to turn to moralistic goals. The superego consists of two systems: The conscience and the ideal self. The conscience can punish the ego through causing feelings of guilt. The ideal self (or ego-ideal) is an imaginary picture of how you ought to be, and represents career aspirations, how to treat other people, and how to behave as a member of society.

Data 8

She was achingly effortless, and she would never, in a million years, choose me. But, for the next few minutes, I contented myself with magnificent possibility that she might. (ScHneider. 2013: 67)

Ezra looked at Cassidy when they were at the park where he realized that she was really pretty. He likes her, but he knew that she would not like him back, but he hoped that maybe she might with a slight possibility. His Id told him that there was no way that Cassidy would like him because she was a smart and beautiful person but he went against his Id. What Ezra did was considered to be the moral of act because he never forced his feelings towards Cassidy where he just hid it to maintain his friendship with Cassidy.

\section{Conclusion}

Based on the analysis of the novel entitled The Beginning of Everything in 2013, it could be concluded that:

The five points in presenting a character's personality proposed by 
Kenney (1966) consisting of Discursive method, Character on character method, Dramatic method, Contextual method, and Mixing method are all applied in the novel.

According to Freud (1896), psychological analysis is divided into three major personalities, consisting of Id, Ego, and Superego. The relation between the Id, Ego, and Superego are connected with each other which are considered to be the basic knowledge in determining a personality.

\section{Bibliography}

Freud, Sigmund. 1988. The Standard Edition of the Complete Psychological Works. New York: International Universities Press, Inc.

Freud, Sigmund. 1998. Psychoanalysis: Freud's Revolutionary Approach to Human Personality.Cited from http://www.personalityresearch.org/p apers/beystehner.html. Accessed at September $5^{\text {th }}, 2017,11.23 \mathrm{a} . \mathrm{m}$

Kenney, William. 1966. How to Analyze Fiction. New York: Monarch Press

McLeod, Saul. 2007. Id, Ego, Superego. Cited from https://www.simplypsychology.org/p syche.html. Accessed at October $5^{\text {th }}$, 2017, 08.15a.m

ScHneider, Robyn. 2013. The Beginning of Everything. New York: HarperCollins Publishers

Welleck, Rene and Warren, Austin. 1970. Theory of Literature. New York: Harcourt, Bace \& World

Punch. K. 1998. Introduction to Social Research: Quantitative and
Qualitative Approaches. London: Sage 